\title{
ORIGINAL
}

\section{Lung histopathological findings in fatal pandemic influenza A (H1N1)}

\author{
N. Nin a,b , C. Sánchez-Rodríguez ${ }^{a, b}$, L.S. Ver ${ }^{b, c}$, P. Cardinal ${ }^{d}, A$. Ferruelo $^{a, b}$, \\ L. Soto ${ }^{e}$, A. Deicas ${ }^{d}$, N. Campos $^{f}$, O. Rocha ${ }^{g}$, D.H. Ceraso ${ }^{h}$, M. El-Assar ${ }^{a, b}$, \\ J. Ortín ${ }^{\mathrm{b}, \mathrm{c}}$, P. Fernández-Segoviano ${ }^{\mathrm{a}, \mathrm{b}}$, A. Esteban ${ }^{\mathrm{a}, \mathrm{b}}$, J.A. Lorente ${ }^{\mathrm{a}, \mathrm{b}, *}$ \\ a Hospital Universitario de Getafe, Madrid, Spain \\ b CIBER de Enfermedades Respiratorias, Instituto de Salud Carlos III, Madrid, Spain \\ c Centro Nacional de Biotecnología, CSIC, Madrid, Spain \\ ' Sanatorio Casmu, Montevideo, Uruguay \\ e Instituto Nacional de Tórax, Santiago de Chile, Chile \\ ${ }^{\mathrm{f}}$ Hospital Regional de Salto, Salto, Uruguay \\ ' Sanatorio GREMEDA, Artigas, Uruguay \\ ${ }^{\mathrm{h}}$ Hospital Juan A. Fernández, Buenos Aires, Argentina
}

Received 18 July 2011; accepted 19 October 2011

Available online 10 December 2011

\section{KEYWORDS \\ H1N1; \\ ARDS; \\ Lung pathology; \\ Mechanical \\ ventilation}

\begin{abstract}
Objective: To describe the lung pathological changes in influenza A ( $\mathrm{H} 1 \mathrm{~N} 1)$ viral pneumonia. We studied morphological changes, nitro-oxidative stress and the presence of viral proteins in lung tissue.

Methods and patients: Light microscopy was used to examine lung tissue from 6 fatal cases of pandemic influenza A ( $\mathrm{H} 1 \mathrm{~N} 1)$ viral pneumonia. Fluorescence for oxidized dihydroethydium, nitrotyrosine, inducible NO synthase (NOS2) and human influenza A nucleoprotein (NP) (for analysis under confocal microscopy) was also studied in lung tissue specimens.

Results: Age ranged from 15 to 50 years. Three patients were women, and 5 had preexisting medical conditions. Diffuse alveolar damage (DAD) was present in 5 cases (as evidenced by hyaline membrane formation, alveolo-capillary wall thickening and PMN infiltrates), and interstitial fibrosis in one case. In the fluorescence studies there were signs of oxygen radical generation, increased NOS2 protein and protein nitration in lung tissue samples, regardless of the duration of ICU admission. Viral NP was found in lung tissue samples from three patients. Type I pneumocytes and macrophages harbored viral NP, as evidenced by confocal immunofluorescence microscopy.

Conclusions: Lung tissue from patients with pandemic influenza A $(\mathrm{H} 1 \mathrm{~N} 1)$ viral pneumonia shows histological findings consistent with DAD. Prolonged nitro-oxidative stress is present despite antiviral treatment. Viral proteins may remain in lung tissue for prolonged periods of time, lodged in macrophages and type I pneumocytes.

(C) 2011 Elsevier España, S.L. and SEMICYUC. All rights reserved.
\end{abstract}

\footnotetext{
* Corresponding author.

E-mail address: jlorente.hugf@salud.madrid.org (J.A. Lorente).
} 


\section{PALABRAS CLAVE \\ H1N1; \\ SDRA; \\ Histopatología de \\ pulmón; \\ Ventilación mecánica}

\section{Resultados histopatológicos pulmonares en la gripe A (H1N1) pandémica letal}

\section{Resumen}

Objetivo: Describir la histopatología pulmonar de pacientes que fallecieron con neumonía por virus de la influenza A (H1N1), el tipo celular infectado por el virus y la presencia de stress oxidativo y nitrosativo.

Métodos: Hemos examinado tejido pulmonar de 6 pacientes fallecidos en la $\mathrm{UCI}$ con el diagnóstico de infección por el virus influenza A (H1N1) (15-50 años de edad) mediante (i) microscopía óptica, (ii) microscopia confocal con tinciones específicas para diferentes tipos celulares (aquoporina 5, factor Von Willebrand, proteína D del surfactante), (iii) inmunofluorescencia (IF) para sonda de dihidroetidio oxidado, óxido nítrico sintasa inducible (NOS2), anti-3-nitrotirosina y nucleoproteína (NP) del virus de la influenza A (H1N1).

Resultados: (1) En 5 casos se encontró daño alveolar difuso (DAD), evidenciado mediante la observación de membranas hialinas, engrosamiento de la pared alveolo-capilar e infiltración de PMN, asociado con hemorragia intensa en un paciente. Un caso presentó fibrosis intersticial. (2) Se demostró en todos los casos aumento de la inmuno-reactividad para DHE oxidado, NOS2 y 3-nitrotirosina independientemente de la duración de la estancia en la UCI. (3) Se encontró NP viral en tres pacientes. (4) El virus se localiza en los neumocitos tipo I y en macrófagos alveolares.

Conclusiones: El tejido pulmonar de pacientes fallecidos con neumonía por virus de la influenza A (H1N1) evidencia hallazgos histológicos compatibles con DAD. El estrés nitro-oxidativo prolongado está presente a pesar del tratamiento antiviral. Las proteínas virales pueden permanecer en el tejido pulmonar durante períodos prolongados de tiempo, albergándose en los macrófagos y neumocitos tipo I.

(c) 2011 Elsevier España, S.L. y SEMICYUC. Todos los derechos reservados.

\section{Introduction}

Previous reports have analyzed the clinical profile, organ dysfunction and mortality risk factors in patients with H1N1 influenza virus infection. ${ }^{1-6}$ These patients were usually young, often developed acute respiratory distress syndrome (ARDS) and shock, and had a high associated mortality rate, posing a management challenge for physicians. ${ }^{7-10}$

Lung histopathology in influenza A (H1N1) virus was first reported in autopsy studies during the 1918 and 1957 pandemics. ${ }^{10}$ More recently, in the recent 2009 pandemics, several studies have confirmed the presence of diffuse alveolar damage with thick hyaline membranes formation, accompanied in some cases by necrotizing bronchiolitis and extensive hemorrhage. ${ }^{1,7-9,11}$

The specific cell type targeted by the virus has been reported by Gill et al. ${ }^{11}$ who showed in 34 patients who died following confirmed H1N1 infection that influenza viral antigen was observed most commonly in the epithelium of the tracheobronchial tree, in type I and type II alveolar epithelial cells and in macrophages. In line with these findings, Mauad et al. ${ }^{7}$ found small vesicles containing one viral particle enveloped by the pneumocyte II membrane.

It has been shown that increased nitric oxide (NO) and reactive oxygen species formation plays a critical role in lung dysfunction in acute lung injury and ARDS. ${ }^{12-14}$ In the present study we analyzed light microscopy findings as well as changes in the nitro-oxidative stress in lung tissue samples from fatal cases diagnosed of pandemic 2009 influenza A (H1N1) viral pneumonia and ARDS.

\section{Methods}

\section{Patients}

With our local Ethics' Committee, 6 patients ( 3 from Uruguay, 1 from Chile, 1 from Argentine and 1 from Spain) who died in the Intensive Care Unit (ICU) with H1N1 influenza viral pneumonia were studied. Each center's institutional review board approved the study. The Ethics Committee of the Hospital Universitario de Getafe classified this as an exempt study. Lung tissue samples were examined in the Department of Pathology and in the Research Unit of Hospital Universitario de Getafe. Lung tissue samples from 2 patients who died in the ICU without lung clinical diagnosis and normal lungs under light microscopy served as controls.

Clinical information was obtained from medical charts. The diagnosis of H1N1 influenza virus infection was made by real-time reverse transcription polymerase chain reaction (PCR) in accordance with the guidelines from the Centers for Disease Control and Prevention (CDC).

\section{Tissue processing}

The lung was carefully removed from the thorax (the tracheobronchial tree was not fixed), and then instilled with $10 \%$ formalin. Within $36-48 \mathrm{~h}$ after death lung tissue was sliced sagitally in $1.0-1.5 \mathrm{~cm}$ thickness sections, and blocks were taken for paraffin inclusion and microscopic study after hematoxylin-eosin (HE), Masson trichromic and PAS staining. 


\section{Fluorescence for oxidized dihydroethidium}

Formalin (10\%) fixed, paraffin-embedded transverse lung tissue sections ( $5 \mu \mathrm{m}$ thick) were mounted on poly-L-lysinecoated glass slides. After dewaxing, sections were incubated for $90 \mathrm{~min}$ at $37^{\circ} \mathrm{C}$ with the fluorescent probe dihydroethidium ([DHE], $4 \mu \mathrm{mol} / \mathrm{l}$; Calbiochem, Darmstadt, Germany). In the presence of reactive oxygen species, DHE is oxidized to ethidium, which intercalates with DNA, staining the nucleus with a bright red fluorescence. Then sections were incubated with 4',6-diamidino-2-phenylindol dihydrochloride $(300 \mathrm{nM})$ (DAPI; Sigma Chemical, St Louis, MO, USA) for $5 \mathrm{~min}$ at $37^{\circ} \mathrm{C}$ reactive with fluorescent blue, marking the interlayer between DNA pair bases in the cell nuclei. After washing with PBS plus $0.1 \%$ Triton $\mathrm{X}-100$, sections were mounted and visualized by microscopy (Olympus BX51, Japan). ${ }^{15}$

\section{Immunofluorescence staining for viral nucleoprotein, NOS2 and nitrotyrosine}

Five- $\mu \mathrm{m}$ sections of formalin (10\%) paraffin-fixed lung tissues were dewaxed, and irradiated with microwave in $0.01 \mathrm{M}$ sodium citrate buffer $(\mathrm{pH} \mathrm{6.0)}$ ) and blocked with $5 \%$ bovine serum albumin (BSA) $0.1 \%$ Triton $\mathrm{X}-100$ in PBS for $2 \mathrm{~h}$ at $37^{\circ} \mathrm{C}$, and incubated overnight at $4{ }^{\circ} \mathrm{C}$ with several antibodies: rabbit polyclonal anti-nitrotyrosine antibody (dilution 1:100; Chemicon International, USA); rabbit polyclonal NOS2 antibody (dilution: 1:50) (Santa Cruz Biotechnology, Inc. Santa Cruz, CA, USA); and rabbit polyclonal antibody against nucleoprotein (NP) of human influenza A (H3N2) (dilution $1: 5000)$ as the three primary antibodies. Human epithelial cells A540 were infected with H1N5 for positive controls (data not shown). Following washes in PBS plus $0.1 \%$ Triton $X-100$, sections were incubated with secondary Alexa Fluor $^{\circledR}$ 546-conjugated goat anti-rabbit antibody (dilution 1:100; Invitrogen, Molecular Probes, Inc. Oregon, USA) for $45 \mathrm{~min}$ at $37^{\circ} \mathrm{C}$. Next, sections were incubated with DAPI $(300 \mathrm{nM})$ for $5 \mathrm{~min}$ at $37^{\circ} \mathrm{C}$. After further washing in PBS, sections were mounted and visualized by microscopy. The specificity of the immunostaining was evaluated by omission of the primary antibody (negative control). ${ }^{16}$

Dual labeling for fluorescence microscopy was performed according to the double indirect immunofluorescence method. ${ }^{17}$ For double immunofluorescence labeling, the rabbit or rat polyclonal antibody against influenza A virus NP was used in conjunction with the following primary antibodies: (1) goat polyclonal IgG antibody against aquoporin 5 (AQP5) (Santa Cruz Biotechnology, Inc., Santa Cruz, CA, USA) used at a dilution of 1:50; (2) polyclonal rabbit anti-human factor VIII (DAKO Diagnostika, Hamburg, Germany) used at a dilution of $1: 100$; (3) monoclonal mouse antibody against surfactant protein D (Abcam, Cambridge, UK) used at a dilution of 1:10; and (4) monoclonal mouse anti-human CD-68 (for macrophages) (DAKO Diagnostika, Hamburg, Germany) used at a dilution of 1:100. Paraffin sections of human lungs were incubated overnight at $4{ }^{\circ} \mathrm{C}$ with a combination of the two primary antibodies. After thorough washing, sections were incubated with a mixture of two secondary antibodies, which consisted of Alexa Fluor ${ }^{\circledR} 488$-conjugated donkey antigoat antibody (dilution 1:100; Invitrogen, Molecular Probes,
Inc., Oregon, USA), FITC-labeled goat anti-mouse IgG (dilution 1:100; Santa Cruz Biotechnology, Inc., Santa Cruz, CA, USA), Alexa Fluor ${ }^{\circledR}$ 546-conjugated goat anti-rabbit antibody (dilution 1:100; Invitrogen, Molecular Probes, Inc., Oregon, USA), donkey anti-rabbit 594, goat anti-rabbit 488 and goat anti-rat 594 for $45 \mathrm{~min}$ at $37^{\circ} \mathrm{C}$ in the dark. In all samples, these reactions were followed by nuclear counterstaining for $5 \mathrm{~min}$ at $37^{\circ} \mathrm{C}$ with DAPI (300 nM). Sections were studied under confocal microscopy (Leica SP5, IL, USA). Immunofluorescence negative controls were preparations lacking the primary antibody from the staining procedure.

\section{Cross-reactivity of H3N2 viral NP with H1N1 viral NP}

A consensus sequence was originated from 2439 human $\mathrm{H} 1 \mathrm{~N} 1$ reported in the Influenza virus Resource at NCBI server in the period 2009-2010. ${ }^{18}$ The alignment of this consensus sequence and the NP sequence from A/Victoria/3/75 (Vic) strain $(\mathrm{H} 3 \mathrm{~N} 2)$, the protein used to generate the antibody for our immunofluorescence assays, was then generated with the BioEdit Sequence Alignment Editor program ${ }^{19}$ and a NP protein consensus sequence from H1N1 isolates (http://www.ncbi.nlm.nih.gov/genomes/FLU/FLU.html) showed a $90 \%$ identity and $96 \%$ similarity, indicating a great conservation of the protein. Further, our IF experimental data using H3N2 antibody to identify seasonal and pandemic $\mathrm{H} 1 \mathrm{~N} 1$ virus-infected cells indicate a complete cross-reactivity.

The alignment of the $\mathrm{H} 1 \mathrm{~N} 1$ consensus sequence and $\mathrm{NP} / \mathrm{Vic}$ strain sequence strongly suggested that the polyclonal antibody against the latter could recognize the NP protein from pandemic $\mathrm{H} 1 \mathrm{~N} 1$ virus. This was confirmed by infections with A/WSN (H1N1, positive control) and with pandemic H1N1 isolated (unpublished data) in A549 cells.

\section{Results}

\section{Patients}

All patients were admitted to the ICU and required mechanical ventilation, and all were diagnosed of $\operatorname{ARDS}^{20}$ (Table 1 ). Three patients died within the first 8 days of mechanical ventilation. Five patients received treatment with oseltamivir (for 10 days or less if death occurred earlier) and all received empiric treatment for bacterial infection. Three patients (cases \#3, \#4 and \#6) received corticosteroids. H1N1 influenza virus infection was confirmed by real time reverse transcription PCR, either in nasopharyngeal swab (5 cases) or in lung tissue (case \#1).

\section{Lung pathology}

Five patients showed evidence of acute interstitial lesions characteristic of diffuse alveolar damage (DAD) (cases \#1 to \#5, Table 1). In these five patients hyaline membranes, type II pneumocyte hyperplasia and interstitial inflammation were observed, as well as alveolar septal edema in three of them (Fig. 1 panels $A$ and $B$ ). Of note, extensive exudate of fibrin-rich edema fluid in the alveolar space was observed 


\begin{tabular}{|c|c|c|c|c|c|c|c|c|c|c|c|c|}
\hline Case & Age & Gender & $\begin{array}{l}\text { Underlying } \\
\text { medical } \\
\text { conditions }\end{array}$ & $\begin{array}{l}\text { Treatment } \\
\text { with } \\
\text { antiviral }\end{array}$ & $\begin{array}{l}\text { Days of } \\
\text { mechanical } \\
\text { ventilation }\end{array}$ & $\begin{array}{l}\text { Cause of } \\
\text { death }\end{array}$ & $\begin{array}{l}\text { Basic } \\
\text { histological } \\
\text { pattern }\end{array}$ & $\begin{array}{l}\text { Hyaline } \\
\text { membranes }\end{array}$ & $\begin{array}{l}\text { Intra- } \\
\text { alveolar } \\
\text { edema }\end{array}$ & $\begin{array}{l}\text { Interstitial } \\
\text { inflamma- } \\
\text { tion }\end{array}$ & $\begin{array}{l}\text { Granulation } \\
\text { tissue repair }\end{array}$ & $\begin{array}{l}\text { Alveolar } \\
\text { hemorrhage }\end{array}$ \\
\hline 1 & 26 & Female & Pregnant & Yes & 1 & Hypoxemia & $\begin{array}{l}\text { Exudative } \\
\text { DAD with } \\
\text { bronchiolitis }\end{array}$ & Moderate & Intense & Mild & - & Mild \\
\hline 2 & 50 & Female & None & Yes & 2 & Hypoxemia & $\begin{array}{l}\text { Exudative } \\
\text { DAD }\end{array}$ & Moderate & Moderate & Moderate & - & Mild \\
\hline 3 & 15 & Male & Asthma & Yes & 8 & Hypoxemia & $\begin{array}{l}\text { Proliferative } \\
\text { DAD }\end{array}$ & Moderate & - & Mild & Moderate & Mild \\
\hline 4 & 37 & Male & Obesity & Yes & 16 & MOF & $\begin{array}{l}\text { Proliferative } \\
\text { DAD with } \\
\text { intense } \\
\text { intra- } \\
\text { alveolar } \\
\text { hemorrhage }\end{array}$ & Mild & Mild & Intense & Moderate & Intense \\
\hline 5 & 22 & Female & Pregnant & Yes & 36 & Hypoxemia & $\begin{array}{l}\text { Proliferative } \\
\text { DAD with } \\
\text { necrotizing } \\
\text { bronchiolitis }\end{array}$ & Mild & - & Intense & Intense & Mild \\
\hline 6 & 32 & Female & $\begin{array}{l}\text { Pregnant } \\
\text { Asthma }\end{array}$ & Yes & 45 & Hypoxemia & $\begin{array}{l}\text { Residual } \\
\text { Fibrosis }\end{array}$ & - & - & Intense & Intense & Mild \\
\hline
\end{tabular}



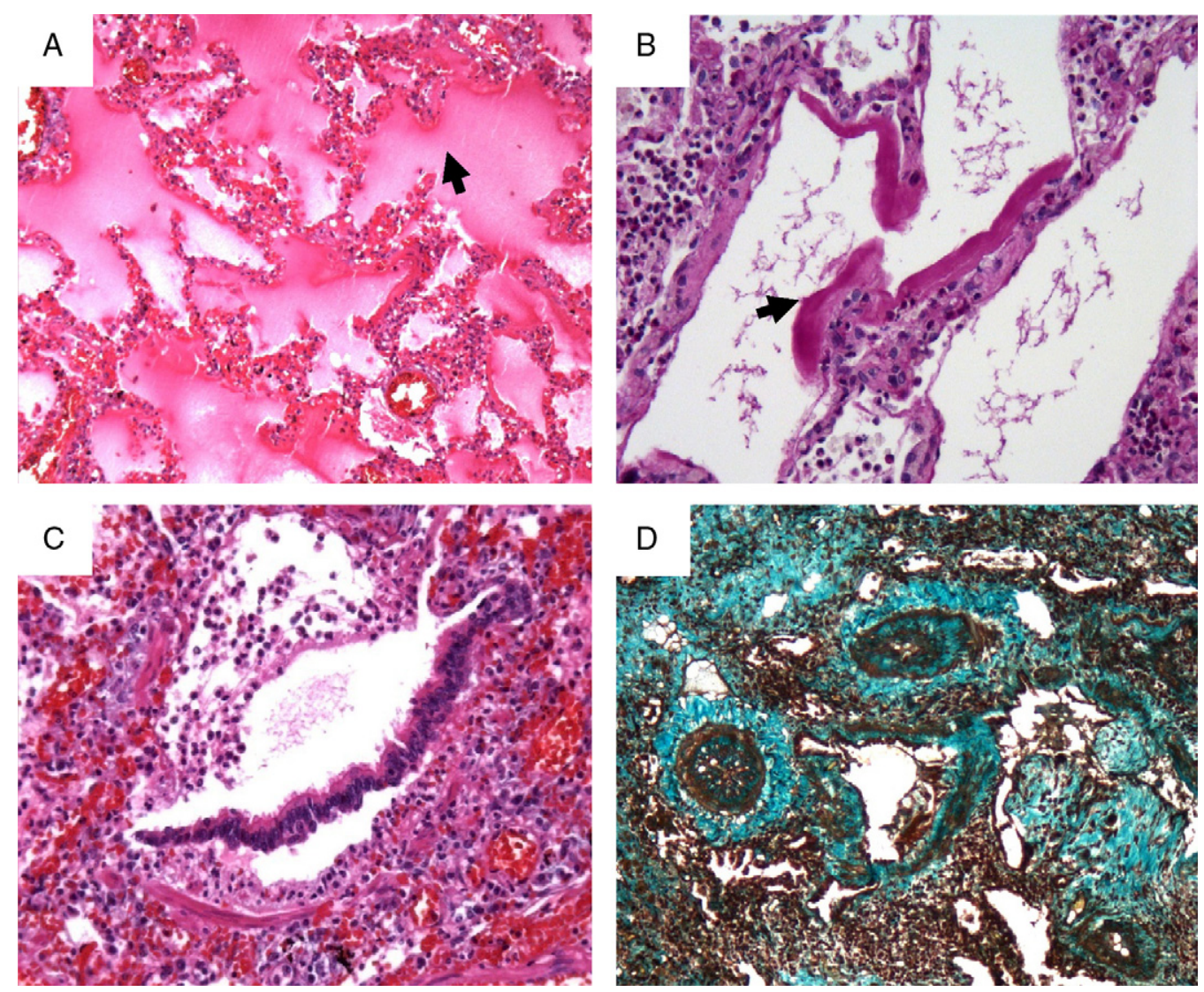

Figure 1 Representative photomicrographs of lung pathology (light microscopy). (A) Extensive exudate of fibrin-rich edema fluid (arrow) was noted in the alveolar space (case \#1) (HE 20×). (B) Signs of diffuse alveolar damage: hyaline membranes lining the alveolar spaces (arrow), and inflammatory cells infiltrates (case \#3) (HE 40×). (C) Interstitial fibrosis with thickening of the muscular artery wall (case \#6) (Masson trichromic 10×). (D) Necrotizing bronchiolitis with desquamation and necrosis of bronchial ciliary epithelium (case \#5) (HE 20×).

in one case who died early after ICU admission (case \#1). Cases \#1 and \#5 also had bronchiolitis (Table 1, Fig. 1 panel C). Granulation tissue was present in cases \#3, \#4, \#5, and \#6, those with the longest time from diagnosis to death. One patient (case \#6) had residual fibrosis with intense granulation tissue repair and interstitial inflammation (Table 1, Fig. 1 panel D). Alveolar hemorrhage of different intensity was found in all patients (Table 1). Signs of DAD evolved over time according to the duration of mechanical ventilation, from exudative (case \#1 and \#2), to proliferative (cases \#3, \#4 and \#5) and to fibrotic changes (case \#6).

\section{Fluorescence studies}

In all cases there was increased reactivity for oxidized DHE, NOS2 protein, and protein nitration, indicating increased nitro-oxidative stress (Fig. 2). The degree of staining ranged from mild to intense, but there was no relationship with the time after diagnosis. Some patients had intense staining after a prolonged period in the ICU (Table 2). Lung tissue from control patients had negative staining for DHE, NOS2 and protein nitration. Thus fluorescence findings in these cases with influenza A ( $\mathrm{H} 1 \mathrm{~N} 1)$ were not due to tissue processing after death.

Immunofluorescence for viral NP was present in 3 cases (cases \#1, \#2, who died in the first 2 days of ICU admission; and case \#5, who died on day 36 after diagnosis) (Table 2, Fig. 3). We examined the specific location of influenza virus NP by confocal microscopy. Positive staining for viral NP was observed in type I pneumocytes (aquoporin 5 positive cells) in one case and in carbon-containing macrophages in all three cases (Fig. 3). Factor VIII and surfactant protein D staining served to rule out type II pneumocyte and endothelial cell location.

\section{Discussion}

Our data on lung pathology in fatal cases of pandemic H1N1 influenza virus infection show that (i) the predominant finding is DAD, with variable degrees of pulmonary hemorrhage and necrotizing bronchiolitis; (ii) there is oxidative and nitrosative stress even in cases dying after prolonged ARDS; (ii) viral proteins may be present in lung tissue despite prolonged treatment; (iv) the virus seems to localize in type I pneumocytes and macrophages. 

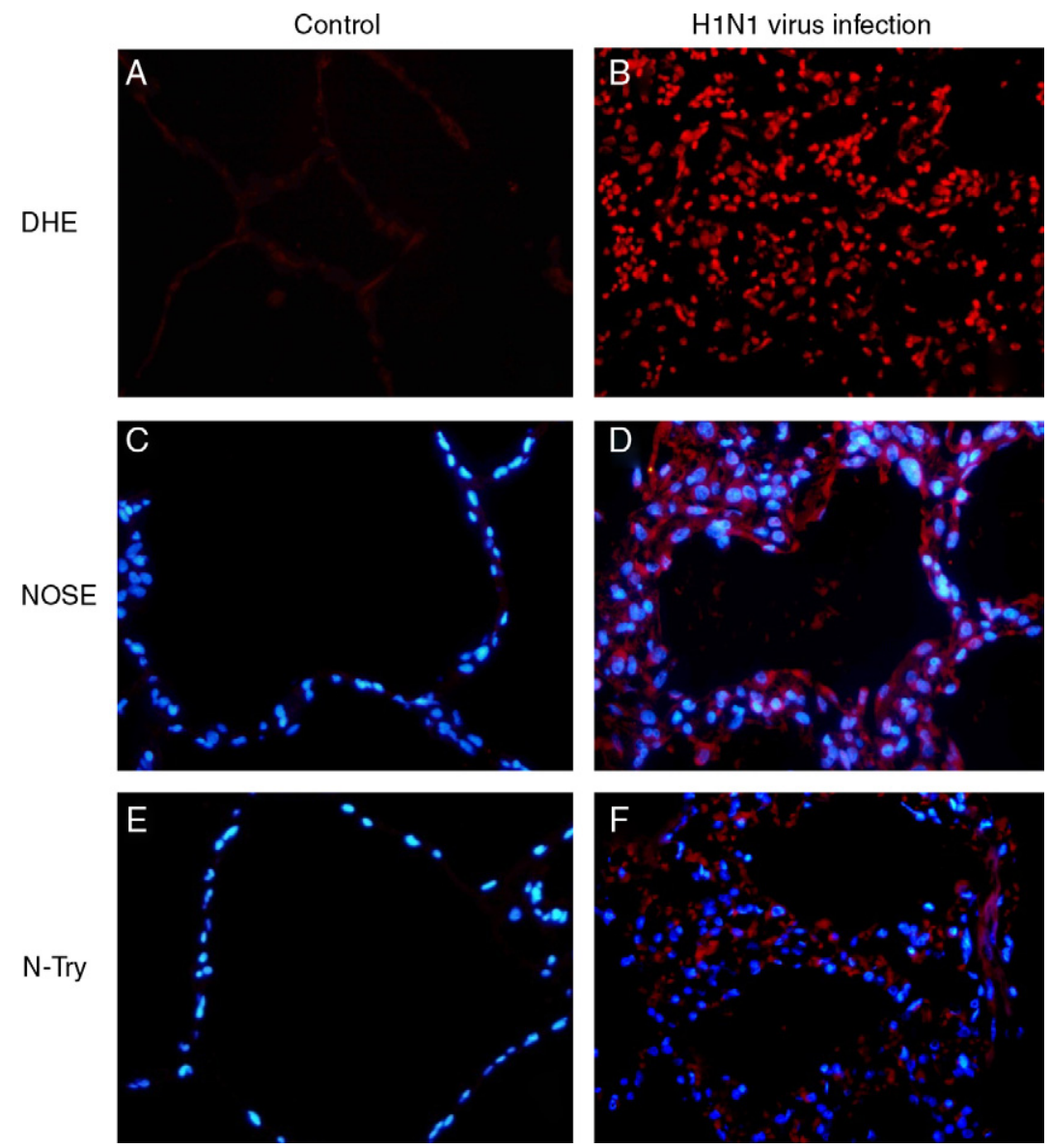

Figure 2 Detection of reactive oxygen species, inducible NO synthase (NOS2) and nitrotyrosine (N-Tyr) in lung tissue. (A, B) Oxidized dihydroethidium in red. (C, D) NOS2 in red, and DAPI, a nuclear marker, in blue. (E, F) N-Tyr in red, and DAPI in blue. Increased oxidative stress, NOS2 protein and protein nitration is appreciated in lung tissue samples from this patient with pandemic influenza H1N1 virus infection (case \#5). Similar findings were observed in all cases studied (original magnification $40 \times$ ).

\section{Lung pathology}

The most predominant pathological findings were those of $\mathrm{DAD}$, accompanied by hemorrhage in all cases and necrotizing bronchiolitis. Our results are in keeping with previous reports on lung pathology in H1N1 influenza. ${ }^{7-9,11}$ Mauad et al. ${ }^{7}$ described three distinct patterns of pulmonary pathological changes: classic exudative DAD, with alveolar and interstitial edema, alveolar fibrinous exudate with hyaline membranes and reactive pneumocytes, accompanied by mild inflammation; severe necrotizing bronchiolitis characterized by extensive necrosis of the bronchiolar wall and dense neutrophilic infiltrate within the bronchiolar lumen, and severe inflammation; and exudative DAD with an intense hemorrhagic component. Other findings in our cases and in prior reports ${ }^{7-9,11}$ included microthrombi or thrombi in large arteries.

In the present series, those cases dying within the first week after diagnosis presented signs of exudative ARDS, whereas those dying after the first week presented signs of proliferative ARDS. The case with the longest ICU stay showed fibrotic changes. These findings support the proposed, but fairly undocumented, time course, of pathological changes in ARDS. ${ }^{21}$

Table 2 NOS2, nitrotyrosine and oxidative stress by fluorescence in lung tissue samples.

\begin{tabular}{lllll}
\hline Case & NOS2 & Nitrotyrosine & Dihydroethidium & Nucleoprotein (NP) \\
\hline 1 & Moderate & Moderate & Moderate & Moderate \\
2 & Intense & Intense & Moderate & Intense \\
3 & Intense & Moderate & Moderate & - \\
4 & Mild & Moderate & Intense & - \\
5 & Intense & Mild & Intense & Moderate \\
6 & Intense & Moderate & Moderate & - \\
\hline
\end{tabular}



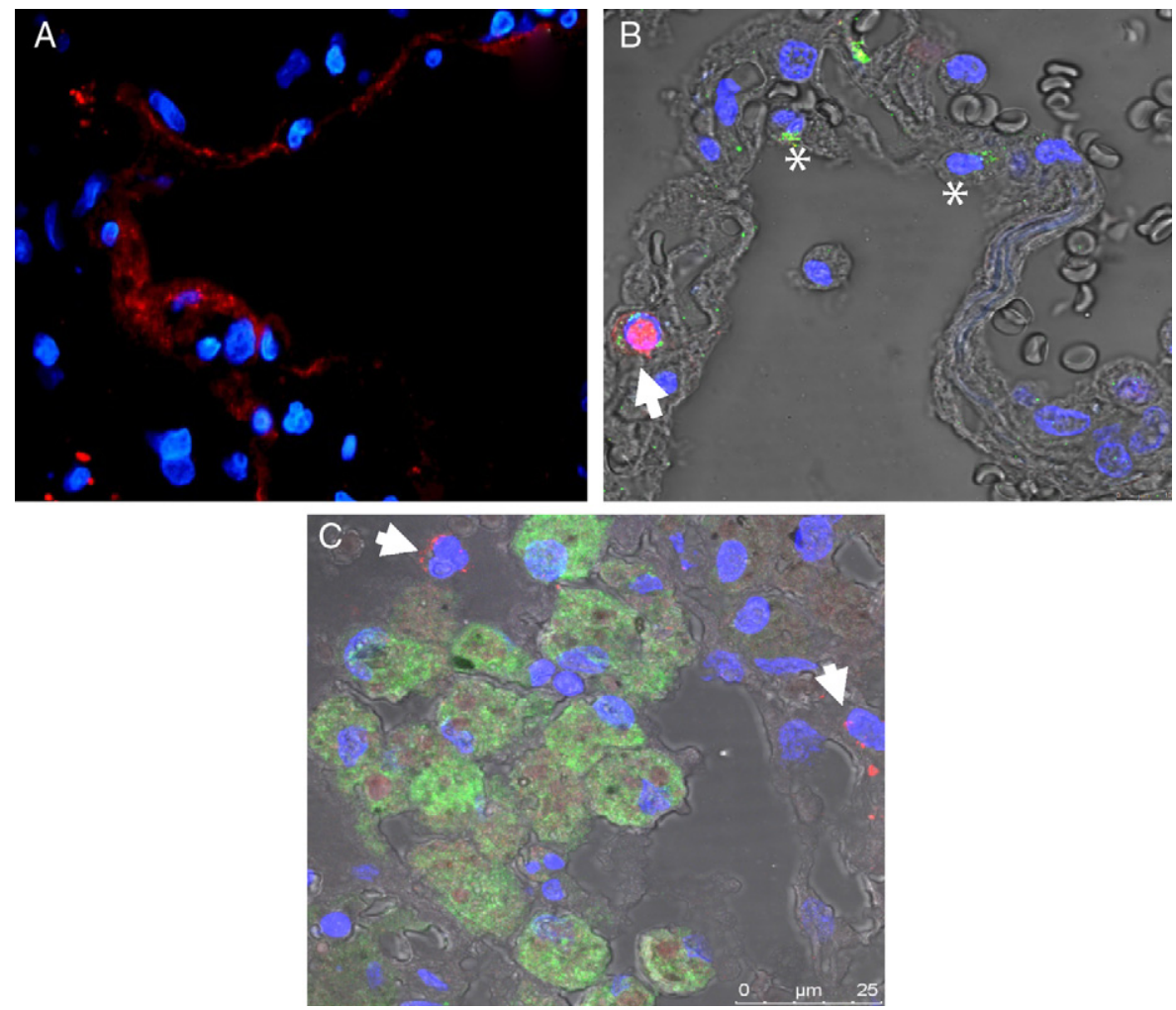

Figure 3 Demonstration of viral nucleoprotein in lung tissue (case \#5, who died after 36 days in the ICU). (A) Immunofluorescence for influenza A virus nucleoprotein (in red) and DAPI, a nuclear marker (in blue) in lung tissue. A linear immunoreactivity for viral nucleoprotein is observed, suggesting protein presence in alveolar lining pneumocytes (original magnification $100 \times$ ). (B) Immunofluorescence for type I pneumocytes (aquoporin 5 positive cells, in green, asterisks) and viral nucleoprotein (in pink). A type I pneumocyte containing viral nucleoprotein is observed (arrow) (confocal scanning microscopy, original magnification 63×). (C) Immunofluorescence for macrophages (in green) and viral nucleoprotein (in red). Several macrophages containing viral nucleoprotein are identified (confocal scanning microscopy, original magnification $63 \times$ ).

\section{Florescence studies: nitro-oxidative stress and viral NP}

The pathogenesis of H1N1 influenza virus infection is still poorly known. Antiviral mechanisms involve the activation of TLRs and cytotoxic CD8+T cells. ${ }^{22,23}$ Increased expression of TLR-3 in macrophages, alveolar epithelial cells and along the alveolar capillaries has been reported, in combination with IFN- $\gamma$ in macrophages, alveolar epithelial cells and vessels, and an increased density of CD8+ T cells and granzyme $\mathrm{B}+$ cells surrounding airways and alveolar walls. ${ }^{22,23}$

Changes in oxidative and nitrosative stress in $\mathrm{H} 1 \mathrm{~N} 1$ influenza virus infection have not been previously reported. Increased nitro-oxidative stress has been shown to play a role in the pathogenesis of ARDS. ${ }^{12-14}$ All our cases showed increased tyrosine nitration in the immunofluorescence studies, which indicates formation of peroxynitrite and subsequent protein nitration. Peroxynitrite formation requires the synthesis of superoxide anion and NO from NOS2, and NOS2 protein was increased in all our cases. In addition, oxidized DHE staining, indicating formation of oxygen free radicals, was increased in all cases. Increased oxidized DHE and nitrotyrosine reactivity was observed even in cases with prolonged ARDS, suggesting a role for prolonged oxidative and nitrosative stress in the pathogenesis of ARDS in H1N1 influenza virus infection.

We did not observe cytopathic effects in our patients. However, Mauad et al. ${ }^{7}$ reported cytopathic effects in the bronchial and alveolar epithelial cells in 5 of 21 patients. In that report $^{7}$ one viral particle was also observed by electronic microscopy as budding from a type II pneumocyte membrane. Recently Gill et al. ${ }^{11}$ showed that influenza viral antigen was observed most commonly in the epithelium of the tracheobronchial tree and macrophages and less frequently in alveolar type I and type II cells. We found viral proteins by confocal microscopy in 3 of the 6 cases, localizing in macrophages and, in one case, in type I pneumocytes. Our original findings, in combination with those of Mauad et al. ${ }^{7}$ and Gill et al. ${ }^{11}$ would support that this virus can probably infect different cell types within the lung. Interestingly, viral NP was present in one of our cases dying 36 days after diagnosis, suggesting that active infection may persist despite a regular 10-day antiviral course. Gill et al. also reported positive immunohistochemistry for influenza A (H1N1) in one case 38 days after hospitalization.

One of the possible limitations of our study is that we utilized an antibody against H3N2, but this antibody has a 
complete cross-reactivity with seasonal and pandemic $\mathrm{H} 1 \mathrm{~N} 1$ virus-infected cells.

In summary we report lung pathological changes in fatal cases of H1N1 influenza virus infection. DAD is the predominant finding, accompanied by alveolar hemorrhage and in some cases by bronchiolitis and microthrombi. Prolonged nitro-oxidative stress can be present. Viral antigens can be found in type I pneumocytes.

\section{Funding}

FIS GR09/0001 and CIBER de Enfermedades Respiratorias, Instituto de Salud Carlos III, Madrid, Spain.

\section{Conflict of interest}

No potential conflict of interest relevant to this article was reported by any of the authors.

\section{Acknowledgements}

We thank Mrs. Mar Granados from the Pathology Department of Hospital Universitario de Getafe for her technical assistance and Eduardo Andrade M.D. from the Pathology Department of Hospital Regional de Salto, Uruguay.

\section{References}

1. Perez-Padilla $R$, de la Rosa-Zamboni $D$, Ponce de Leon $S$, Hernandez M, Quiñones-Falconi F, Bautista E, et al. Pneumonia and respiratory failure from swine-origin influenza $A(\mathrm{H} 1 \mathrm{~N} 1)$ in Mexico. N Engl J Med. 2009;361:680-9.

2. González-Vélez AE, Díaz-Agero-Pérez C, Robustillo-Rodela A, Cornejo-Gutiérrez AM, Pita-López MJ, Oliva-Iñiguez L, et al. Factors associated to admission to intensive care in patients hospitalized due to pandemic Influenza A/H1N1 2009. Med Intensiva. 2011;35:463-9.

3. Rello J, Rodríguez A, Ibañez P, Socias L, Cebrian J, Marques A, et al. H1N1 SEMICYUC Working Group Intensive care adult patients with severe respiratory failure caused by influenza $A$ (H1N1) in Spain. Crit Care. 2009;13:R148.

4. Rodríguez A, Martin-Loeches I, Bonastre J, Olaechea P, Alvarez-Lerma F, Zaragoza R, et al. SEMICYUC-CIBERES-REIPI working group. First influenza season after the 2009 pandemic influenza: report of the first 300 ICU admissions in Spain. Med Intensiva. 2011;35:208-16.

5. Rodríguez A, Socías L, Guerrero JE, Figueira JC, González N, Maraví-Poma E, et al. Pandemic influenza A in the ICU: experience in Spain and Latin America GETGAG/SEMICYUC/(Spanish Work Group on Severe Pandemic Influenza A/SEMICYUC). Med Intensiva. 2010;34:87-94.

6. Domínguez-Cherit G, Lapinsky SE, Macias AE. Critically ill patients with 2009 influenza A (H1N1) in Mexico. JAMA. 2009;302:E1-8.

7. Mauad T, Hajjar LA, Callegari GD, da Silva LF, Schout D, Galas FR, et al. Lung pathology in fatal novel human influenza A (H1N1) infection. Am J Respir Crit Care Med. 2010;181:72-9.
8. Mukhopadhyay S, Philip AT, Stoppacher R. Pathologic findings in novel influenza A (H1N1) virus ("swine flu") infection: contrasting clinical manifestations and lung pathology in two fatal cases. Am J Clin Pathol. 2010;133:380-7.

9. Soto-Abraham MV, Soriano-Rosas J, Díaz-Quiñónez A, Silva-Pereyra J, Vazquez-Hernandez P, Torres-López 0 , et al. Pathological changes associated with the $2009 \mathrm{H} 1 \mathrm{~N} 1$ virus. N Engl J Med. 2009;361:2001-3.

10. Taubenberger JK, Morens DM. The pathology of influenza virus infections. Annu Rev Pathol. 2008;3:499-522.

11. Gill JR, Sheng ZM, Ely SF, Guinee DG, Beasley MB, Suh J, et al. Pulmonary pathologic findings of fatal 2009 pandemic influenza A/H1N1 viral infections. Arch Pathol Lab Med. 2010;134:235-43.

12. Gole MD, Souza JM, Choi I, Hertkorn C, Malcolm S, Foust RF, $3 r d$, et al. Plasma proteins modified by tyrosine nitration in acute respiratory distress syndrome. Am J Physiol Lung Cell Mol Physiol. 2000;278:961-7.

13. Lamb NJ, Gutteridge JM, Baker C, Evans TW, Quinlan GJ. Oxidative damage to proteins of bronchoalveolar lavage fluid in patients with acute respiratory distress syndrome: evidence for neutrophil-mediated hydroxylation, nitration, and chlorination. Crit Care Med. 1999;27:1738-44.

14. Martínez-Caro L, Lorente JA, Marín-Corral J, SánchezRodríguez C, Sánchez-Ferrer A, Nin N, et al. Role of free radicals in vascular dysfunction induced by high tidal volume ventilation. Intensive Care Med. 2009;35:1110-9.

15. Peiró C, Lafuente N, Matesanz N, Cercas E, Llergo JL, Vallejo S, et al. High glucose induces cell death of cultured human aortic smooth muscle cells through the formation of hydrogen peroxide. Br J Pharmacol. 2001;133(August):967-74.

16. Peiro C, Matesanz N, Nevado J, Lafuente N, Cercas E, Azcutia V, et al. Glycosylated human oxyhaemoglobin activates nuclear factor-kappaB and activator protein-1 in cultured human aortic smooth muscle. Br J Pharmacol. 2003;140(October): 681-90.

17. Nakajima M, Kawanami O, Jin EJ, Ghazizadeh M, Honda M, Asano $\mathrm{G}$, et al. Immunohistochemical and ultrastructural studies of basal cells, Clara cells and bronchiolar cuboidal cells in normal human airways. Pathol Int. 1998;48:944-53.

18. Hall TA. BioEdit: a user-friendly biological sequence alignment editor and analysis program for Windows 95/98/NT. Nucleic Acids Symp Ser. 1999;41:95-8.

19. Jorba N, Juarez S, Torreira E, Gastaminza P, Zamarreño N, Albar JP, et al. Analysis of the interaction of influenza virus polymerase complex with human cell factors. Proteomics. 2008;8:2077-88.

20. Bernard GR, Artigas A, Brigham KL, Carlet J, Falke K, Hudson L, et al. The American-European Consensus Conference on ARDS. Definitions, mechanisms, relevant outcomes, and clinical trial coordination. Am J Respir Crit Care Med. 1994;149: 818-24.

21. Katzenstein AL, Myers JL. Nonspecific interstitial pneumonia and the other idiopathic interstitial pneumonias: classification and diagnostic criteria. Am J Surg Pathol. 2000;24:1-3.

22. Bruder D, Srikiatkhachorn A, Enelow RL. Cellular immunity and lung injury in respiratory virus infection. Viral Immunol. 2006;19:147-55.

23. Wong JP, Christopher ME, Viswanathan S, Karpoff N, Dai X, Das $D$, et al. Activation of toll like receptor signaling pathway for protection against influenza virus infection. Vaccine. 2009;27:3481-3. 